\title{
Mesenchymal stem cell therapy for acute respiratory distress syndrome: from basic to clinics
}

\author{
Hua Qin ${ }^{1 凶}$ (D), Andong Zhao ${ }^{1,2}$ \\ ${ }^{1}$ Research Center for Tissue Repair and Regeneration Affiliated to the Medical Innovation Research Department, PLA \\ General Hospital and PLA Medical College, Beijing 100853, China \\ 2 Tianjin Medical University, Tianjin 300070, China \\ $\triangle$ Correspondence: qinh0116@126.com (H. Qin) \\ Received March 27, 2020 Accepted May 12, 2020
}

\section{ABSTRACT}

The 2019 novel coronavirus disease (COVID-19), caused by the severe acute respiratory syndrome coronavirus 2 (SARS-CoV-2), has occurred in China and around the world. SARS-CoV-2-infected patients with severe pneumonia rapidly develop acute respiratory distress syndrome (ARDS) and die of multiple organ failure. Despite advances in supportive care approaches, ARDS is still associated with high mortality and morbidity. Mesenchymal stem cell (MSC)-based therapy may be an potential alternative strategy for treating ARDS by targeting the various pathophysiological events of ARDS. By releasing a variety of paracrine factors and extracellular vesicles, MSC can exert anti-inflammatory, antiapoptotic, anti-microbial, and pro-angiogenic effects, promote bacterial and alveolar fluid clearance, disrupt the pulmonary endothelial and epithelial cell damage, eventually avoiding the lung and distal organ injuries to rescue patients with ARDS. An increasing number of experimental animal studies and early clinical studies verify the safety and efficacy of MSC therapy in ARDS. Since low cell engraftment and survival in lung limit MSC therapeutic potentials, several strategies have been developed to enhance their engraftment in the lung and their intrinsic, therapeutic properties. Here, we provide a comprehensive review of the mechanisms and optimization of MSC therapy in ARDS and highlighted the potentials and possible barriers of MSC therapy for COVID-19 patients with ARDS.
KEYWORDS mesenchymal stem cells, cell therapy, acute respiratory distress syndrome, SARS-CoV-2, COVID19 , pneumonia

\section{THE EPIDEMIOLOGY OF NOVEL CORONAVIRUS DISEASE 2019 (COVID-19) AND THE MANAGEMENT OF ARDS}

Since December 2019, an increasing number of patients have been infected by severe acute respiratory syndrome coronavirus 2 (SARS-CoV-2), which causes pneumonia in China (Chan et al., 2020; Chen et al., 2020a; Chinazzi et al., 2020; Ghinai et al., 2020; Guan et al., 2020; Kucharski et al., 2020; Le et al., 2020). The SARS-CoV-2 pneumonia is defined as a novel coronavirus disease 2019 (COVID-19) by World Health Organization (WHO). Human-to-human transmission has been occurring, and infections have been rapidly spreading in China and around the world (Chen et al., 2020a; Chinazzi et al., 2020; Kucharski et al., 2020). Some patients with severe pneumonia rapidly develop acute respiratory distress syndrome (ARDS) and require intensive care unit (ICU) admission (Guan et al., 2020; Holshue et al., 2020; Sun et al., 2020; Xu et al., 2020a). At this stage, patients worsen in a short period and die of multiple organ failures, such as severe respiratory failure, heart failure, and renal failure. As SARS-CoV-2 is an emerging virus infection, the pathological changes happening in severe patients need to be fully understood, and no effective treatment has been developed to prevent worsening of these severe patients 
and to treat ARDS due to pneumonia. Current management for SARS-CoV-2-infected patients with severe pneumonia and ARDS remains supportive, including anti-infection, intubated ventilator-assisted breathing therapy, and extracorporeal membrane oxygenation (ECMO) (Chen et al., 2020a; Guan et al., 2020; Kandel et al., 2020; Le et al., 2020; $\mathrm{Xu}$ et al., 2020a). Since ARDS is associated with high mortality and morbidity, it is urgent to develop new effective approaches to the control of ARDS.

ARDS is a devastating disorder characterized by acute and refractory hypoxia noncardiogenic pulmonary edema, diffuse alveolar-capillary membrane damage, and reduced compliance (Ranieri et al., 2012). Despite decades of research, there is still no effective pharmacotherapy for ARDS. Although some supportive care approaches are established, ARDS remains devastating and life-threatening (Bellani et al., 2016; Papazian et al., 2019).

A growing body of evidence has shown that cell-based therapy holds therapeutic effects for ARDS. Most studies have focused on the therapeutic effects of mesenchymal stem cells (MSCs), although some studies have also investigated the possible applications of pluripotent stem cells, pulmonary epithelial progenitors, and endothelial progenitor cells (Laffey and Matthay, 2017; Han et al., 2019; Lopes-Pacheco et al., 2019). Mounting studies have examined the efficacy of MSC therapy across a wide array of experimental ARDS models (Table 1). Importantly, some clinical trials have been completed or are in progress to evaluate the safety and efficacy of MSC therapy in patients with ARDS and COVID-19, shown in Table 1 (Zheng et al., 2014; Wilson et al., 2015; Matthay et al., 2019; Bing et al., 2020; Leng et al., 2020).

In this review, we discussed the mechanisms of MSCs in treating ARDS and the optimization of MSC therapy and highlighted the perspectives related to the therapeutic applications of MSCs in COVID-19 patients with ARDS.

\section{MECHANISMS OF MSC ADOPTIVE TRANSFER IN TREATING ARDS}

MSCs are harvested from a variety of sources, including the bone marrow, adipose tissue, placenta, and umbilical cord blood (Le Blanc and Mougiakakos, 2012). MSCs possess specific properties that make them attractive candidates for therapeutic use in kinds of diseases, including inflammatory autoimmune diseases, tissue damage repair, etc. They are non-immunogenic, have low tumorigenicity and short lifespan in vivo, possess immunomodulatory and anti-inflammatory effects, and also can detect injured microenvironments and direct their responses for triggering the regeneration process (Stappenbeck and Miyoshi, 2009; Le Blanc and Mougiakakos, 2012). Preclinical and clinical studies have suggested that in vivo administration of MSCs exerts anti-inflammatory and anti-apoptotic effects, enhances epithelial and endothelial cell recovery, promotes microbial and alveolar fluid clearance, and reduces lung and distal organ injuries in the treatment of ARDS (Fig. 1).

\section{INDUCTION OF ANTI-INFLAMMATORY RESPONSE}

In vivo transfer of MSCs can mitigate inflammation by reducing levels of inflammatory mediators and increasing levels of anti-inflammatory and pro-resolution factors in experimental ARDS models (Fig. 1). The anti-inflammatory effects of MSCs have been mostly attributed to their release of paracrine factors, because of low engraftment of donorderived MSCs into at the host lung tissue after MSC therapy (Qin et al., 2012; Millar et al., 2019). In support of this, MSCconditioned media have been suggested to reduce pro-inflammatory mediator levels and inflammatory cell counts in ARDS models (lonescu et al., 2012; Goolaerts et al., 2014; Chen et al., 2015; Su et al., 2019; Xu et al., 2019). It was recently shown that certain therapeutic effects of MSCs depend on their ability to secrete extracellular vesicles. Extracellular vesicles can transfer messenger RNA (mRNA), microRNA, proteins, lipids, and even organelles such as mitochondria to the target cells and tissues, altering gene expression and modulating the behavior of target cells to attenuate the inflammatory response, consequently mediating and exerting MSC therapeutic effects (Hao et al., 2019; Lee et al., 2019; Abraham and Krasnodembskaya, 2020).

Accumulating evidence demonstrates that patients with severe COVID-19 suffer from the hyperinflammatory syndrome or cytokine storm syndrome, characterized by hypercytokinaemia, such as an increase in the levels of interleukin (IL)-1 $\beta$, IL-2, Interferon $\mathrm{y}$-induced protein 10 (IP10), granulocyte colony-stimulating factor (GCSF), IL-7, interferon $\mathrm{Y}$ (IFNY), monocyte chemotactic protein 1 (MCP1), macrophage Inflammatory Protein $1 \alpha$ (MIP1 $\alpha$ ), and Tumor necrosis factor a (TNFa) (Chen et al., 2020a; Haberman et al., 2020; Koff and Williams, 2020; Mehta et al., 2020; Schett et al., 2020). A retrospective, multicentre study of 150 COVID-19 patients, showed that the patients that died had higher levels of serum ferritin, C-reactive proteins, and IL-6 as compared to the survivors, indicating that hyperinflammation contributed to death (Schett et al., 2020; Stebbing et al., 2020; Vaninov, 2020). Similarly, a retrospective, multicentre cohort study containing 191 COVID-19 patients also found increased ferritin and IL-6 (Mehta et al., 2020; Vaninov, 2020). Yang et al., conducted a multiplex screen for 48 cytokines in 53 moderate and severe COVID-19 patients and revealed a significant increase in the levels of 14 cytokines in COVID-19 patients as compared with healthy controls. Among them, the increased IP-10, MCP3, hepatocyte growth factor (HGF), monokine induced gamma interferon (MIG), and MIP1 $\alpha$ were closely linked to the disease severity (Yang et al., 2020). Moreover, highly proinflammatory monocyte-derived $\mathrm{FCN1}^{+}$macrophages were present in bronchoalveolar lavage fluid of the severe COVID-19 patients but not the mild patients (Liao et al., 2020). A markedly higher number of $\mathrm{CD} 14^{+} \mathrm{CD} 16^{+}$inflammatory 


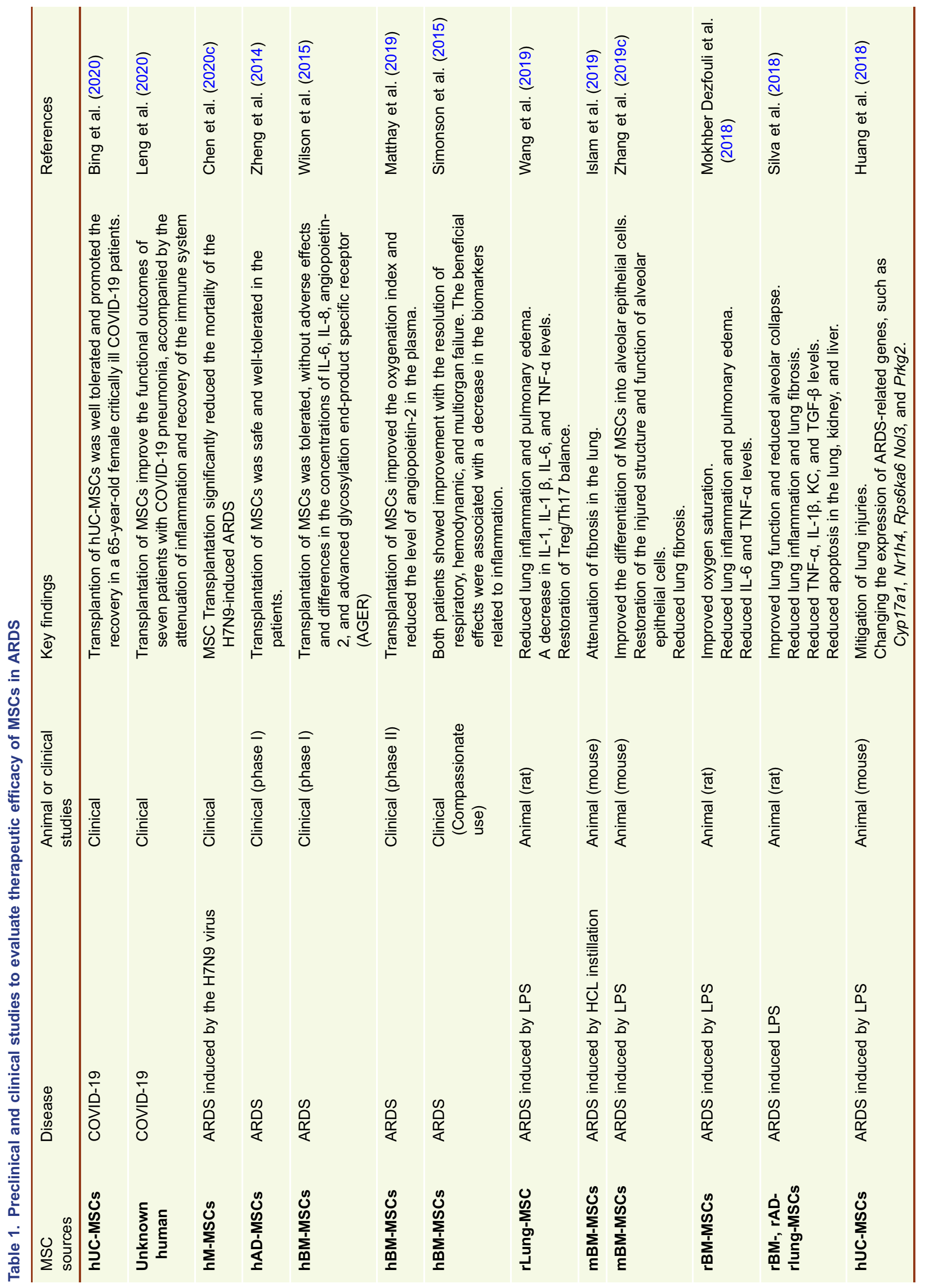




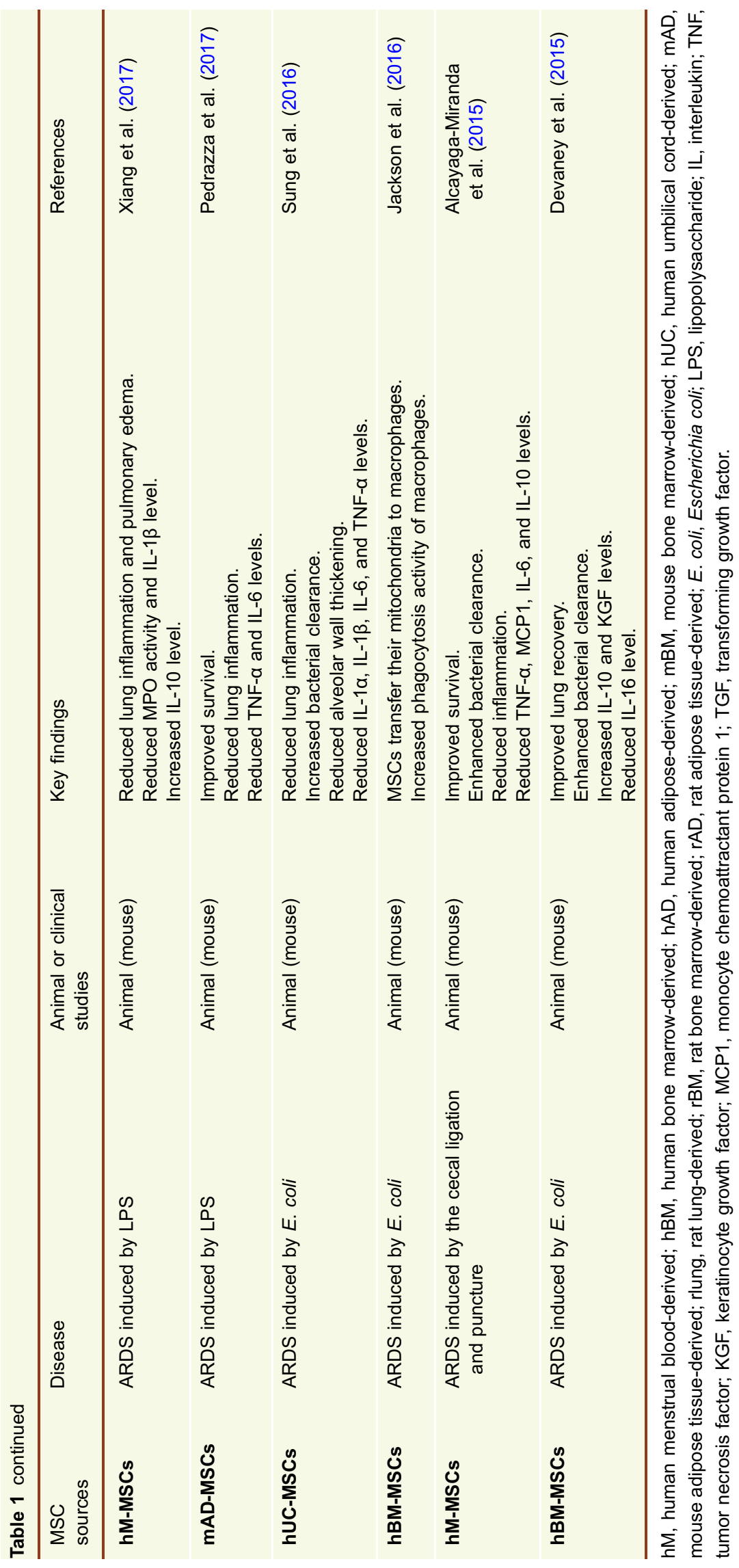




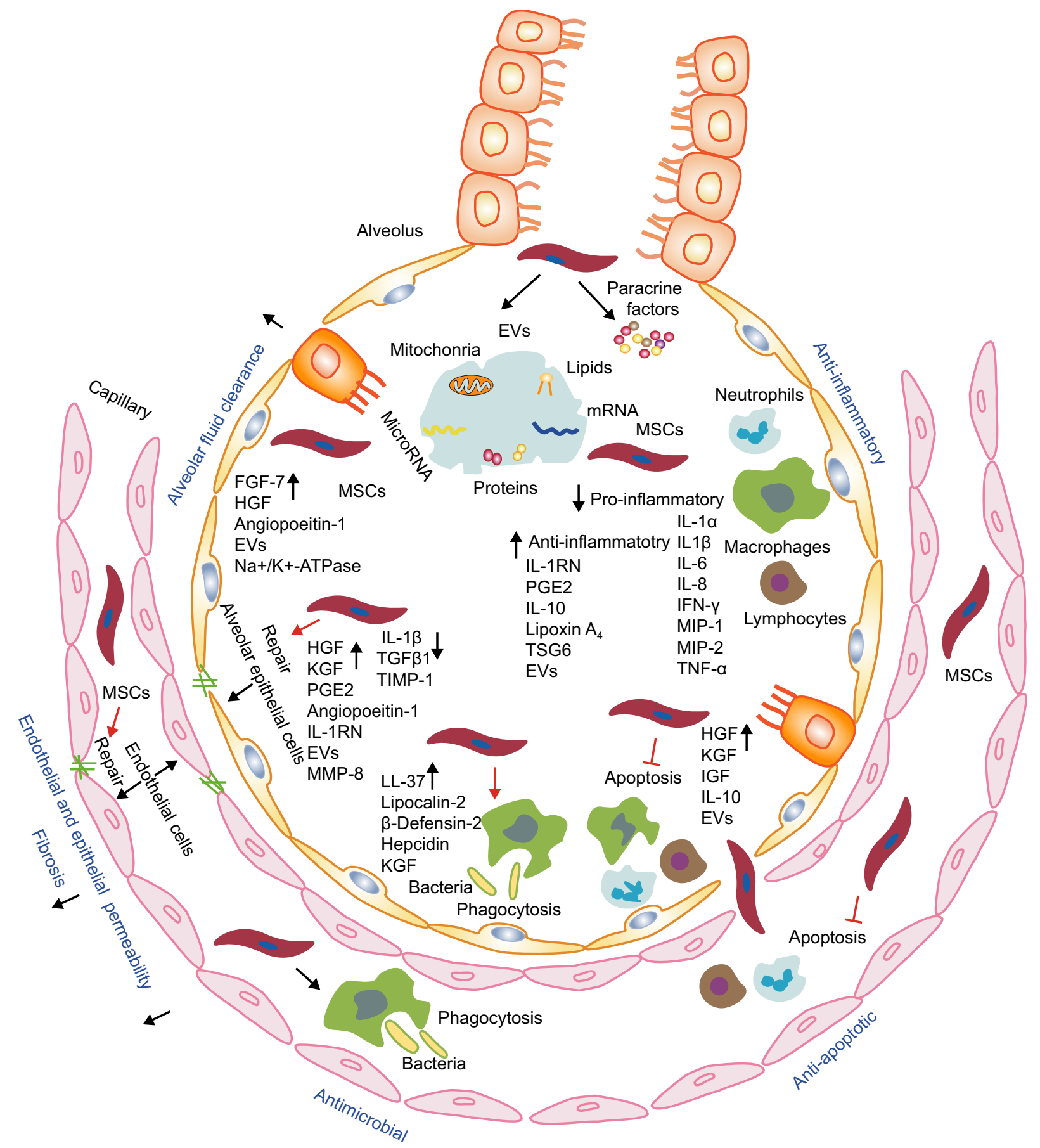

Figure 1. The mechanisms of MSC therapy in ARDS. The therapeutic effects of MSCs in ARDS involve multiple mechanisms via their secretion of soluble paracrine protein factors and extracellular vesicles (EVs). MSCs can exert anti-inflammatory, anti-apoptotic, and anti-microbial effects, protect the pulmonary endothelial and alveolar epithelial cells, enhance alveolar fluid clearance, and inhibit lung fibrosis.

monocytes were observed in the peripheral blood of severe COVID-19 patients compared to mild cases (Zhou et al., $2020 b)$. These data suggest that anti-inflammatory effects conferred by MSCs might suppress the hyperinflammatory syndrome in severe COVID-19 patients. 


\section{REDUCTION OF CELL APOPTOSIS}

Apoptosis of both resident and immune cells contribute to ARDS progression, as apoptotic cells recruit inflammatory cells and result in tissue remodeling. In vivo administration of MSCs into ARDS models can reduce the apoptotic cell counts in the lung tissues and distal organs in ARDS (Silva et al., 2018). MSCs have also been reported to reduce apoptosis of the alveolar epithelial cells and endothelial cell by secretion of keratinocyte growth factor (KGF), angiopoietin-1, and HGF (Bernard et al., 2018; Chen et al., 2019a; Meng et al., 2019). Alveolar macrophage apoptosis induced by lipopolysaccharide (LPS) was also attenuated after MSC treatment, which may be partially mediated by inhibition of the Wnt/ $\beta$-catenin pathway (Li et al., 2015). A reduction of tumor necrosis factor- $\alpha$ (TNF- $\alpha$ ) that induces cell death may also contribute to the anti-apoptotic effects of MSC therapy (Kim et al., 2011; Güldner et al., 2015).

Lymphocytopenia is common in COVID-19 patients, which mostly impairs the CD4 ${ }^{+} \mathrm{T}_{\text {cell }}$ subsets (Chen et al., 2020b; Goyal et al., 2020; Yang et al., 2020). The apoptosis of lymphocytes induced by SARS-CoV-2 infection leads to lymphocytopenia in critically ill patients with COVID-19 pneumonia (Chen et al., 2020b; Zheng et al., 2020). Mild patients have only mild lymphocytopenia, whereas severe patients have severe lymphocytopenia, suggesting apoptosis of lymphocytes reflects the severity of COVID-19 pneumonia to some extent. Moreover, SARS-CoV-2 infection results in apoptosis of alveolar epithelial cells and endothelial cells (Monteil et al., 2020; Varga et al., 2020; Walls et al., 2020). For this reason, MSC-based therapy may bring about beneficial effects for COVID-19 patients possibly by inhibiting apoptosis of resident cells and immune cells.

\section{INITIATION OF THE ANTI-MICROBIAL INNATE RESPONSE}

MSCs therapy has been proven to promote bacterial clearance in the lung in animal models of ARDS. Such effects of MSCs are associated with the secretion of anti-microbial peptides and proteins, including LL-37, lipocalin-2, and $\beta$ defensin-2, hepcidin, and KGF (Krasnodembskaya et al., 2010; Gupta et al., 2012; Alcayaga-Miranda et al., 2015; Sung et al., 2016). Alternative mechanisms underlying the bacterial clearance by MSCs include, at least partially, the enhancement of the phagocytic activity of macrophages and monocytes via promoting mitochondrial transfer via tunneling nanotubes in the model of ARDS (Krasnodembskaya et al., 2012; Lee et al., 2013; Jackson et al., 2016). Therefore, these studies together show that MSCs can enhance the innate immune responses against bacterial infection via direct and indirect mechanisms.

Some critically ill patients with COVID-19 had co-infections of bacteria and fungi. A retrospective study of 113 deceased patients showed many of them developed secondary bacterial infections, which were highly associated with death (Chen et al., 2020b). Another study of 339 elderly patients with COVID-19 showed that about $42 \%$ of the patients developed bacterial infections, and bacterial infection was increased significantly in dead patients (Wang et al., 2020a). Empirical antibacterial therapy could promote recovery (Chen et al., 2020b). It is speculated that MSC transplantation may mitigate bacterial infections in severe patients with COVID-19.

\section{PROTECTION OF PULMONARY ENDOTHELIAL CELLS AND ALVEOLAR EPITHELIAL CELL DAMAGE}

Breakdown of alveolar-capillary membrane integrity is a hallmark of ARDS, which contributes to edema formation and tissue remodeling. MSC therapy has been shown to preserve or restore the alveolar epithelial and pulmonary endothelial lining by secreting HGF via extracellular vesicles, reducing inflammatory damage, and increasing autophagy (Yang et al., 2015b; Zhou and You, 2016; Hu et al., 2018; Meng et al., 2019). MSC therapy has also been demonstrated to differentiate directly into type II alveolar epithelial cells for the regeneration by activation of wnt/ $\beta$-catenin signaling (Liu et al., 2013; Cai et al., 2015; Li et al., 2017; Zhang et al., 2019b). In addition to differentiation into alveolar epithelial cells, MSCs can protect the alveolar epithelial cells against the inflammation-induced damage and oxidative injuries by secretion of angiopoietin-1, interleukin 1 (IL-1) receptor antagonist (IL-1RN), prostaglandin E2 (PGE2), HGF, and KGF or scavenging oxidants and radicals (Fang et al., 2010; Goolaerts et al., 2014; Bernard et al., 2018; Yan et al., 2019). Moreover, MSCs can regulate tissue remodeling processes and attenuate the lung fibrosis by increasing metalloproteinase (MMP)-8 and decreasing the levels of tissue inhibitor of metalloproteinase (TIMP)-1, IL-1 $\beta$, and transforming growth factor- $\beta 1$ (TGF- $\beta 1$ ) in the animal model of ARDS (Maron-Gutierrez et al., 2013; Silva et al., 2018). Taken together, MSCs can protect pulmonary endothelial and epithelial cell damage and restore their impaired barrier functions.

The SARS-CoV-2 infects the host using the angiotensinconverting enzyme II (ACE2) receptor (Lan et al., 2020; Shang et al., 2020; Wang et al., 2020b; Yan et al., 2020; Yuan et al., 2020; Zhao et al., 2020; Zhou et al., 2020a), which is widely expressed on the alveolar epithelial type II cells and the endothelial cells in the lung and many other organs, including the heart, liver, kidney, and intestines. In patients with COVID-19, post-mortem analysis demonstrated that the SARS-CoV-2 infected the endothelial cells in the lungs, kidneys, intestines, hearts, and livers and caused endotheliitis and endothelial apoptosis (Varga et al., 2020). Moreover, the SARS-CoV-2 binds to endothelial cells in the lungs and subsequently activates bradykinin 1 receptor (B1R) and B2R on endothelial cells, which result in lung angioedema (van de Veerdonk et al., 2020). In vitro, SARS- 
CoV-2 can infect the human-engineered blood vessel organoids (Monteil et al., 2020). Alveolar epithelial type II cells produce surfactants that can reduce surface tension, which is essential for the gas exchange function. SARS-CoV-2 viruses infect alveolar epithelial type II cells and result in severe injuries to them in COVID-19 patients (Walls et al., 2020; Zhao et al., 2020; Zhou et al., 2020a). The observation of severe injuries to endothelial cells and alveolar epithelial type II cells by SARS-CoV-2 infection may provide a rationale for MSC transplantation therapy to protect the endothelial cells and alveolar epithelial cells in COVID-19 patients.

\section{IMPROVEMENT OF ALVEOLAR FLUID CLEARANCE}

Removal of excessive alveolar and interstitial fluid facilitates lung function recovery in ARDS, as fluid impairs surfactant concentration and gas exchange. MSCs can improve alveolar fluid clearance by the secretion of paracrine factors and regulating the function of membrane channels and transporters. In vivo administration of MSCs has been shown to increase the alveolar fluid clearance in ARDS models and in ex vivo perfused human lung that is injured by endotoxin or Escherichia coli (Lee et al., 2013; Hao et al., 2015; Park et al., 2019; Zhang et al., 2019b). These effects may be associated with the secretion of fibroblast growth factor-7 (FGF-7) and extracellular microvesicles (Park et al., 2019). In a lung injury model induced by influenza infection, treatment with MSCs promotes the alveolar fluid clearance by secreting angiopoietin-1 and KGF and suppressing the downregulation of $\mathrm{Na}^{+} / \mathrm{K}^{+}$-ATPase (Chan et al., 2016). In the bronchoalveolar lavage fluid collected from COVID-19 patients, a large number of SARS-CoV-2 viruses are detected (Lu et al., 2020; Zhou et al., 2020a), and highly inflammatory monocyte-derived $\mathrm{FCN}^{+}$macrophages are present and responsible for producing enormous cytokines (Liao et al., 2020), indicating inflammatory microenvironment in the alveolar fluid. Accordingly, the promotion of alveolar fluid clearance by MSC transplantation may possibly contribute to the recovery of lung function in severe patients with COVID-19.

\section{ATTENUATION OF LUNG AND DISTAL ORGAN INJURIES}

Multiple organ failure can occur as ARDS aggravates, which ultimately results in increased morbidity and mortality. MSC administration can reduce the histopathological impairment of lung tissues and promote the functional recovery in the ARDS models (Mokhber Dezfouli et al., 2018; Silva et al., 2018; Zhang et al., 2019b). Administration of MSCs can also improve the repair and function recovery in other distal organs, including heart (Lee et al., 2009; Golpanian et al., 2016), liver (Lee et al., 2018; Silva et al., 2018), kidney (Perico et al., 2017; Silva et al., 2018), and gut (Garcia-Olmo and Schwartz, 2015; Molendijk et al., 2015). Therefore, MSC administration may not only improve the lung function recovery but also delay or suppress the progression of ARDS into multiple organ injuries. Since ACE2 is expressed in other many organs in addition to lungs, SARS-CoV-2 infection leads to injuries to multiple organs, including heart, kidney, liver, and nervous systems (Li et al., 2020; Ronco and Reis, 2020; Wang et al., 2020a; Xu et al., 2020b; Zhang et al., 2020). Given the confirmed beneficial effects for multiple organs after MSC transplantation, MSCs may be used to prevent and mitigate multiple organ failure in COVID19 patients.

\section{STRATEGIES TO OPTIMIZE MSC THERAPY IN ARDS}

Low engraftment and poor survival of transplanted MSCs are obstacles for clinical translation of this therapy. Several strategies have been developed to improve MSC engraftment and survival in the lung in the experimental models of ARDS (Fig. 2).

The strategies using genetic modification to overexpress beneficial genes on MSCs have enhanced the migration, survival, and therapeutic potential of MSCs transfer in the models of ARDS (Han et al., 2019). Stromal-derived factor-1 (SDF-1) and the chemokine receptor 4 (CXCR4) signaling axis directs the migration of MSCs. However, low expression of CXCR4 on MSCs impairs their homing to the damaged tissues. Overexpression of CXCR4 via viral vector has increased the homing and engraftment of MSCs into the injured lung of LPS-induced lung injury (ALI) or radiationinduced ALI models (Yang et al., 2015a; Zhang et al., 2019a). Similarly, overexpression of another SDF-1 receptor Cxcr7 in MSCs also enhances the therapeutic effects on LPS-ALI model (Shao et al., 2019). PGE2, released in the inflammatory site, can promote the migration of MSCs via activation of the E-prostanoid 2 (EP2) receptor (Goolaerts et al., 2014; Zhu et al., 2017; Xu et al., 2019). MSCs overexpressing EP2 increase their migration to the sites of lung injury in the mouse model of LPS-ALI (Han et al., 2019). In addition to improving the migration of MSCs, genetic modification enhances the intrinsic capacity of MSCs to reduce inflammation and apoptosis. Heme oxygenase-1 ( $\mathrm{HO}-1)$ is a stress-response protein that has anti-inflammatory, antiapoptotic, and anti-oxidative effects. Compared to the unmodified MSCs, MSCs transfected with $\mathrm{HO}-1$ gene show higher potential to ameliorate cytokine levels in serum and the neutrophil counts and total protein concentration in the bronchoalveolar lavage fluid, and improve the histological structure of the injured lung in the LPS-induced ALI rat model (Chen et al., 2018; Chen et al., 2019b). Angiotensin-converting enzyme 2 (ACE2) can protect against lung injury by degrading the profibrotic peptide angiotensin II. Overexpression of the ACE2 gene in bone marrow-derived MSCs has been reported to increase the potential of MSCs to migrate to lung tissue, mitigate the inflammation, and endothelial injury in the LPS-induced ALI mouse model (He 
et al., 2015; Xu et al., 2018). Growth factors, such as HGF (Hu et al., 2016; Chen et al., 2017a; Meng et al., 2019), KGF (Chen et al., 2013), and angiopoietin-1 (Mei et al., 2007; Xu et al., 2008; Shao et al., 2018), have shown pro-angiogenic, anti-inflammatory, anti-oxidative, and pro-proliferation effects. MSCs modified with these growth factor genes have significantly improved their therapeutic effects on lung injury. Overexpression of anti-inflammatory and anti-oxidative molecules, including soluble IL-1 receptor-like-1 (sST2) (Martínez-González et al., 2013), developmental endothelial locus-1 (Del-1) (Zhao et al., 2014), and manganese superoxide dismutase (Chen et al., 2017b), in MSCs also have shown an enhanced ability to treat lung injury.

Nevertheless, viral transfection is associated with the risk of triggering oncogenes and tumorigenesis. Moreover, the establishment of genetically modified MSCs is time-consuming, and it may be hard to administrate genetically modified MSCss immediately following the onset of ARDS. An alternative approach, such as preparation and modification of allogenic MSCs to set up a cell bank for the application needs to be established.

A series of preconditioning strategies have been developed to enhance the therapeutic capacity of MSCs in animal ARDS models. Hypoxic culture of MSCs can stimulate the secretion of bioactive molecules, including vascular endothelial growth factor (VEGF), angiopoietin 1, HGF, insulin-like growth factor 1 (IGF-1), and bal-2, which are associated with pro-angiogenic, anti-apoptotic, and anti-oxidative effects (Chacko et al., 2010; Zhang et al., 2014). Treatment with hypoxia-conditioned MSCs also extends the survival of engrafted cells, improves pulmonary respiratory functions, and reduced inflammatory and pro-fibrotic factor production (Lan et al., 2015). Pre-treatment with N-Acetylcysteine, a precursor of glutathione with anti-oxidative effect, has been demonstrated to strengthen the therapeutic potential of MSCs in ALI mouse models by increasing MSC engraftment and survival rate in the lung tissue (Wang et al., 2013). Pre-activation with serum obtained from ARDS patients enhances the anti-inflammatory capacity of MSCs, evidenced by an increase in the secretion of IL-10 and IL-1RN (Bustos et al., 2013). Moreover, the serum-preactivated MSCs are more effective in reducing lung injury scores, inflammatory cell counts, and pulmonary edema after transplantation into a mouse model of ARDS (Bustos et al., 2013). Moreover, pretreatment with low levels of TGF- $\beta 1$ has been shown to increase the MSC survival in the lung following transplantation in a rat model of LPS-induced ALI ( $\mathrm{Li}$ et al., 2016). These preconditioning strategies might be
Figure 2. The strategies to optimize MSC therapy in ARDS. MSCs can be genetically modified to overexpress beneficial genes or pre-treated with a series of preconditioning strategies, which can promote their therapeutic effects. The improvment of therapeutic effects may depend on an increase in the engraftment and survival of MSCs in the lung, a decrease in the oxidative injury, and enhanced effects of anti-inflammation, antiapoptosis, and angiogenesis.

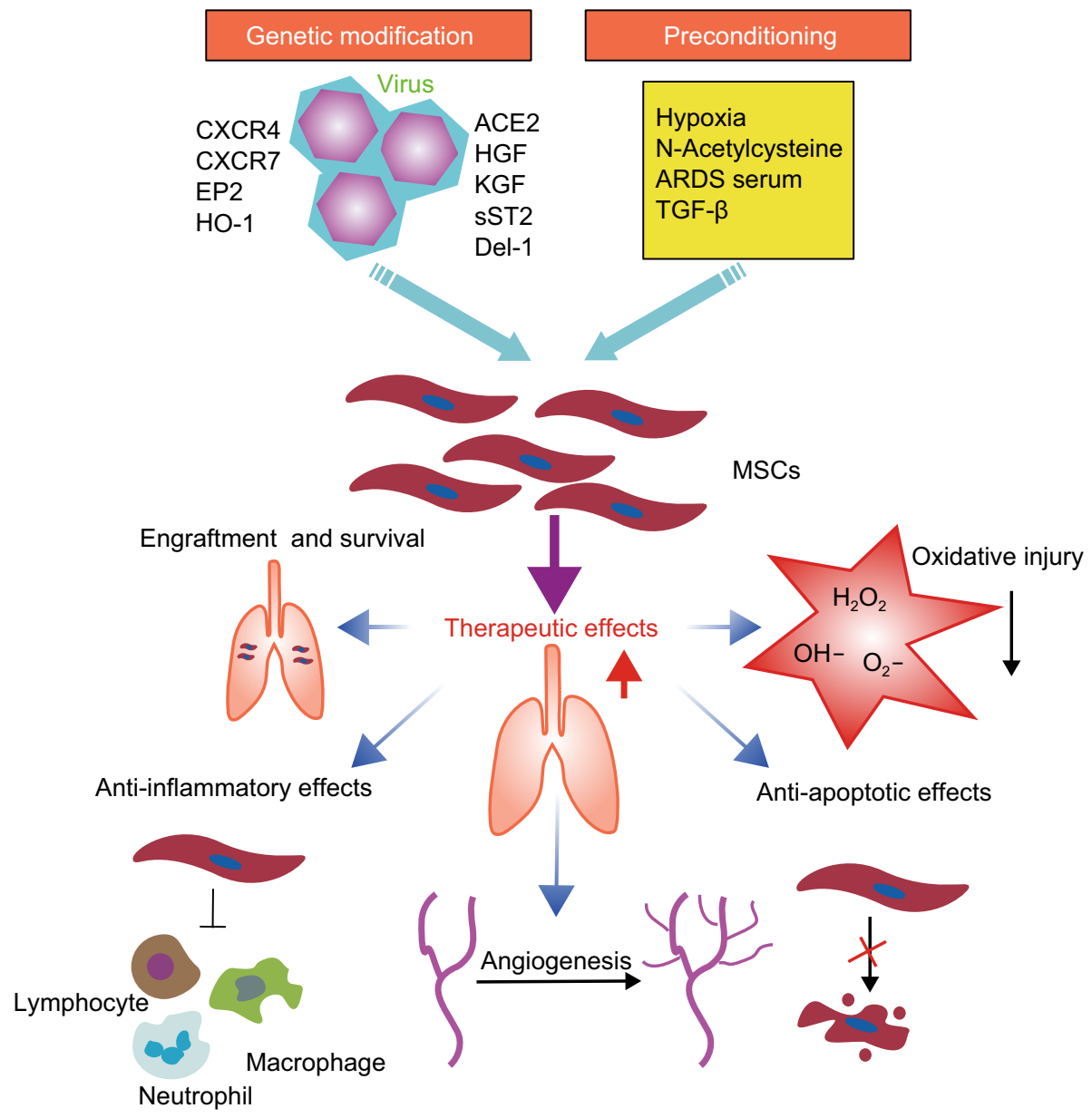


promising for increasing MSC potency in the management of ARDS.

\section{CLINICAL TRIALS OF MSC THERAPY IN PATIENTS WITH ARDS}

To date, 13 clinical trials assessing the safety and efficacy of MSC therapy in ARDS patients have been registered in the US National Institutes of Health (https://clinicaltrials.gov). Three clinical trials have been completed. The first study to evaluate the safety of MSCs in treating ARDS patients was conducted in China (NCT01902082). Zheng et al., conducted a phase I, single-center, randomized, double-blind, placebo-controlled clinical trial, in which ARDS patients received an intravenous injection of allogenic adiposederived MSCs $\left(1 \times 10^{6}\right.$ cells $\left./ \mathrm{kg}\right)$ (Zheng et al., 2014). The in vivo administered MSCs seemed to be safe and welltolerated in the patients. The two groups showed no significant difference in the length of hospital day, ventilator-free days, and ICU-free days within 4 weeks after the treatment (Zheng et al., 2014). Wilson et al., conducted another multicenter, open-label, dose-escalation, phase I clinical trials in the USA (NCT01775774) (Wilson et al., 2015). Patients with moderate-severe ARDS received a single intravenous injection of allogeneic bone marrow-derived MSCs at 1, 5, 10 $\times 10^{6} \mathrm{cells} / \mathrm{kg}$. All dose levels were tolerated, without administration-related adverse effects. No significant differences were observed in the concentrations of related biomarkers such as IL-6, IL-8, angiopoietin-2, and advanced glycosylation end-product specific receptor (AGER) (Wilson et al., 2015). The same group continued to conduct phase lla clinical trials, in which patients received a high dose level of allogeneic bone marrow MSCs $\left(10 \times 10^{6}\right.$ cells $\left./ \mathrm{kg}\right)$ (NCT02097641) (Matthay et al., 2019). No MSC-related hemodynamic and respiratory adverse effects were observed in all patients. Patients receiving MSC treatment showed an improvement in the oxygenation index. A reduced level of angiopoietin-2 in the plasma was found, indicating that MSC administration attenuated endothelial injury. In a Swedish case report, two patients with severe, refractory ARDS received an intravenous infusion of allogeneic bone marrow-derived MSCs $\left(2 \times 10^{6}\right.$ cells $\left./ \mathrm{kg}\right)$ at a compassionate use (Simonson et al., 2015). Both patients showed improvement with the resolution of respiratory, hemodynamic, and multiorgan failure. The beneficial effects were associated with a decrease in the biomarkers related to inflammation (Simonson et al., 2015). In addition, transplantation of menstrual blood-derived MSCs could reduce the mortality in patients with $\mathrm{H} 7 \mathrm{~N} 9$ virus-induced ARDS without adverse effects after the five-year follow-up period in China (Chen et al., 2020c). Because H7N9 and COVID-19 share similar complications, MSC transplantation may be useful for treating COVID-19.

In China, about 10 clinical trials have been registered in the Chinese Clinical Trial Registry (http://www.chictr.org.cn/) to investigate the safety and efficacy of transplantation therapy of bone marrow or umbilical cord mesenchymal stem cells for COVID-19 patients with severe pneumonia or ARDS. Liang and colleagues reported that transplantation of human umbilical cord-derived MSCs could modulate the immune response and promote the functional recovery in a 65-year-old female patient with critically ill COVID-19 and severe complications such as respiratory failure and multiple organ failure (Bing et al., 2020). The patient received three doses of $5 \times 10^{7}$ million allogeneic umbilical cord-MSCs every three days. Following the second dose, the vital signs were improved, and she did not require the ventilator. Two days after the third dose, she was transferred out of the ICU. Recently, one published study involved 7 COVID-19 patients ( 1 critically serious ill, 4 serious ill, and 2 commons) in the MSC-treated group and 3 patients in the control group, with a 14-day follow-up (Leng et al., 2020). In the MSC-treated group, patients received one dose of MSC injection at $1 \times$ $10^{6}$ cells per kilogram of weight. No serious adverse side effects were observed in the MSC-treated groups. All the 7 patients in the MSC-treated group recovered. A few days after MSC transplantation, oxygen saturation and biomarkers for inflammation were decreased, and peripheral lymphocytes were increased. Moreover, transplanted MSCs were negative for ACE2, indicating MSCs are free from SARS-CoV-2 infection. This study suggests that MSCs can suppress hyperinflammation and improve the immune system. Some other study groups have also reported beneficial effects of MSC therapy for COVID-19 before the publication of their data. Accordingly, Atluri and colleagues consider MSCs as a potential alternative therapy for treating critically ill COVID-19 patients (Atluri et al., 2020).

\section{CHALLENGES FOR CLINICAL USE OF MSC THERAPY IN ARDS}

Despite remarkable advances in the control of ARDS with MSC therapy, further research is needed to elucidate several issues, including the optimal MSC source and dose, the time window of MSC administration, administration routes, and frequency (single vs. multiple-dose regimen). Although bone marrow is the most common source for isolating MSCs, the harvesting procedure is invasive, and the cell numbers are limited. Moreover, ARDS affects the immunomodulatory effects of bone marrow MSCs and impairs their potential use for autologous transplantation (Antebi et al., 2018). Although several studies have evaluated the therapeutic effects of MSCs from other sources in ARDS (Zheng et al., 2014; Ren et al., 2018; Silva et al., 2018), it remains unclear about which one may provide superior therapeutic effects. Cell doses are critical for the clinical use of MSC therapy. In experimental models, the number of MSCs administered at a single dose range from $5 \times 10^{4}$ to $3.6 \times 10^{7}$ cells (Mclntyre et al., 2016). In the clinical setting, this range in a $25-\mathrm{g}$ mouse would correspond to $2 \times 10^{6}$ to $1.44 \times 10^{9} \mathrm{cells} / \mathrm{kg}$ in 


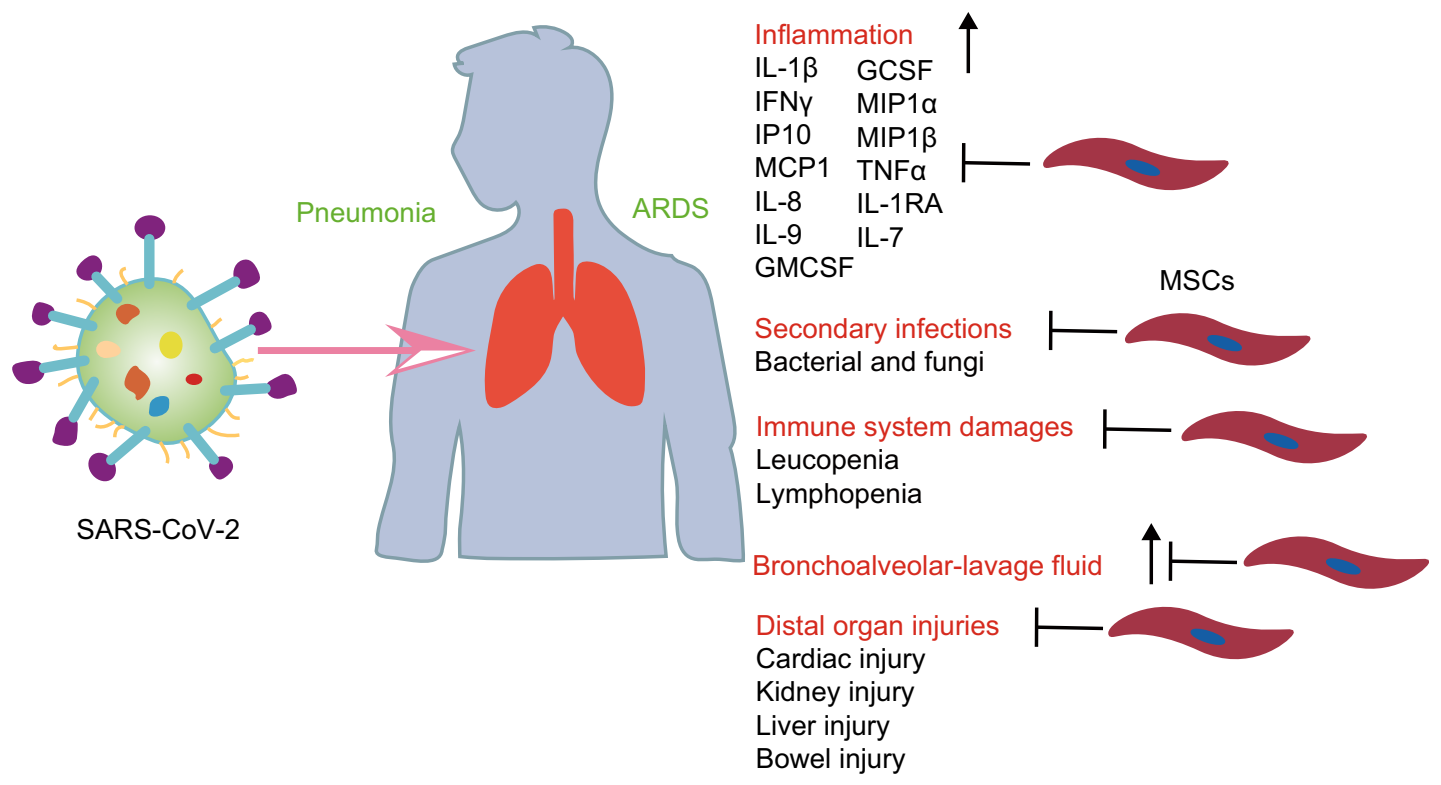

Figure 3. The potential of MSC-based therapy in COVID-19 patients with severe pneumonia and ARDS by targeting pathophysiological changes. SARS-CoV-2 infections caused severe pneumonia and ARDS, with significant pathophysiological changes, including inflammation, immune system damages (leukopenia and lymphopenia), secondary infections, and distal organ injuries. However, MSCs have the potential to target these pathophysiological events, acting as a alternative strategy for treating COVID-19 patients with ARDS.

humans. Such quantities are faced with technical and operational challenges. Of note, some safety concerns may be associated with the use of high doses of MSCs. To date, $1 \times 10^{7}$ cells $/ \mathrm{kg}$ is the highest dose ever used in clinical studies. Accordingly, the optimal number of MSCs administered should be clearly defined for treating ARDS to find a balance between therapeutic effects and undesired safety events. Although a single dose of MSCs has been shown to provide therapeutic benefits, more than one dose may be required to induce a more efficient tissue repair or even to maintain benefits.

The therapeutic window and index for MSC therapies should be further characterized in experimental studies of ARDS. MSC administration has been performed by either local or systemic routes in different experimental models. Local administration via intratracheal infusion delivers cells directly to the site of injury, whereas systemic administration via intravenous infusion allows wide distribution throughout the body. MSCs administered intravenously would encounter the first-class pulmonary effect (Fischer et al., 2009), which results in significant retention of cells in the lung, thereby providing advantages for lung tissue repair. Therefore, ongoing clinical trials and most experimental studies have used the intravenous route for MSC administration. ECMO has been a common therapeutic strategy for patients with severe ARDS. However, MSCs administered intravenously were found to adhere to membrane oxygenator fibers during ECMO in an ex vivo model of ARDS, resulting in a significant reduction of flow through the circuit (Millar et al., 2019).
Thus, MSC transfer should be performed before ECMO or during a pause in the flow or by intratracheal infusion. Especially for patients with severe ARDS requiring continuous high-flow ECMO, intratracheal administration may be optional for this clinical situation.

\section{CONCLUSIONS AND PERSPECTIVES}

Tremendous progress has been made in investigating MSCbased therapy in experimental ARDS models and patients with ARDS. The safety of MSC therapy has also been demonstrated in early-stage clinical studies with a relatively small number of patients.

SARS-CoV-2 infections caused severe pneumonia and ARDS, with significant pathophysiological changes (Fig. 3). Pulmonary inflammation and extensive lung injury are detected, evidenced by high levels of proinflammatory cytokines in serum (eg., IL-1 $\beta$, IFNy, IP10, MCP1, GCSF,

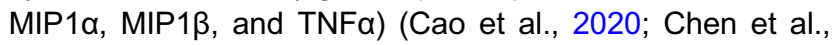
2020a; Haberman et al., 2020; Mehta et al., 2020; Schett et al., 2020). Moreover, patients can have secondary infections. In view of the high levels of cytokines induced by SARS-CoV-2 infections, MSC therapy is likely to reduce inflammation-induced lung injury in SARS-CoV-2-infected patients with ARDS. In addition, the blood counts of patients showed leukopenia and lymphopenia, indicating that SARSCoV-2 consumes immune cells (especially, lymphocytes) and impairs the body's immune system functions (Cao et al., 2020; Chen et al., 2020a). Administration of MSCs may 
promote the recovery of the mounts of white blood cells and lymphocytes because MSCs have shown immunomodulatory and anti-apoptotic effects that protect macrophages, neutrophils, and monocytes against apoptosis. Patients with SARS-CoV-2-infected pneumonia may become worse to develop distal organ injuries such as acute cardiac injury, acute kidney injury, liver injury, and bowel injury (Chan et al., 2020; Chen et al., 2020a; Zhu et al., 2020). Given that the systemic administration of MSC has shown protective effects on these distal organs, MSC treatment may decrease the progression of patients with ARDS into multiple organ failure. Apart from the above benefits, MSC can enhance epithelial and endothelial recovery and promote microbial and alveolar fluid clearance by their paracrine secretion, transfer of extracellular vesicles, or cell-cell contact. Therefore, MSCbased therapy may be a potential alternative strategy for treating COVID-19 patients with ARDS.

\section{ABBREVIATIONS}

ACE2, angiotensin-converting enzyme II; ALI, acute lung injury; ARDS, acute respiratory distress syndrome; B1R, bradykinin 1 receptor; COVID-19, 2019 novel coronavirus disease; CXCR4, chemokine receptor 4; ECMO, extracorporeal membrane oxygenation; EP2, E-prostanoid 2; FGF-7, fibroblast growth factor-7; GCSF, granulocyte colony-stimulating factor; HGF, hepatocyte growth factor; HO-1, Heme oxygenase-1; ICU, intensive care unit; IFN $\gamma$, interferon $\mathrm{Y}$; IL, interleukin; IL-1RN, interleukin 1 receptor antagonist; IP10. Interferon $\mathrm{Y}$-induced protein 10; KGF, keratinocyte growth factor; LPS, lipopolysaccharide; MCP1, monocyte chemotactic protein 1; MIG, monokine induced gamma interferon; MIP1 $\alpha$, macrophage Inflammatory Protein $1 \alpha$; mRNA, messenger RNA; MSC, Mesenchymal stem cell; MMP, metalloproteinase; PGE2, prostaglandin E2; SARS-CoV-2, severe acute respiratory syndrome coronavirus 2; SDF-1, Stromal-derived factor-1; TGF- $\beta 1$, transforming growth factor- $\beta 1$; TIMP, tissue inhibitor of metalloproteinase; TNFa, Tumor necrosis factor $\alpha$

\section{COMPLIANCE WITH ETHICS GUIDELINES}

Hua Qin and Andong Zhao declare that they have no conflict of interest. This article does not contain any studies with human or animal subjects performed by any of the authors.

\section{OPEN ACCESS}

This article is licensed under a Creative Commons Attribution 4.0 International License, which permits use, sharing, adaptation, distribution and reproduction in any medium or format, as long as you give appropriate credit to the original author(s) and the source, provide a link to the Creative Commons licence, and indicate if changes were made. The images or other third party material in this article are included in the article's Creative Commons licence, unless indicated otherwise in a credit line to the material. If material is not included in the article's Creative Commons licence and your intended use is not permitted by statutory regulation or exceeds the permitted use, you will need to obtain permission directly from the copyright holder. To view a copy of this licence, visit http:// creativecommons.org/licenses/by/4.0/.

\section{REFERENCES}

Abraham A, Krasnodembskaya A (2020) Mesenchymal stem cellderived extracellular vesicles for the treatment of acute respiratory distress syndrome. Stem Cells Transl Med 9:28-38

Alcayaga-Miranda F, Cuenca J, Martin A, Contreras L, Figueroa FE, Khoury M (2015) Combination therapy of menstrual derived mesenchymal stem cells and antibiotics ameliorates survival in sepsis. Stem Cell Res Ther 6:199

Antebi B, Mohammadipoor A, Batchinsky Al, Cancio LC (2018) The promise of mesenchymal stem cell therapy for acute respiratory distress syndrome. J Trauma Acute Care Surg 84:183-191

Atluri S, Manchikanti L, Hirsch JA (2020) Expanded Umbilical Cord Mesenchymal Stem Cells (UC-MSCs) as a therapeutic strategy in managing critically ill COVID-19 patients: the case for compassionate use. Pain Physician 23:E71-E83

Bellani G, Laffey JG, Pham T, Fan E, Brochard L, Esteban A, Gattinoni L, van Haren F, Larsson A, McAuley DF et al (2016) Epidemiology, patterns of care, and mortality for patients with acute respiratory distress syndrome in intensive care units in 50 countries. JAMA 315:788-800

Bernard O, Jeny F, Uzunhan Y, Dondi E, Terfous R, Label R, Sutton A, Larghero J, Vanneaux V, Nunes $\mathrm{H}$ et al (2018) Mesenchymal stem cells reduce hypoxia-induced apoptosis in alveolar epithelial cells by modulating HIF and ROS hypoxic signaling. Am J Physiol Lung Cell Mol Physiol 314:L360-L371

Bing L, Jun-hui C, Tao L, Hai-ying W, Wen-jie Y, Yan-jiao L, Jianchun L, Cong-tao Y, Fang-ang N, Zhao-xia M et al (2020) Clinical remission of a critically ill COVID-19 patient treated by human umbilical cord mesenchymal stem cells. ChinaXiv 02.00084v1

Bustos ML, Huleihel L, Meyer EM, Donnenberg AD, Donnenberg VS, Sciurba JD, Mroz L, McVerry BJ, Ellis BM, Kaminski N et al (2013) Activation of human mesenchymal stem cells impacts their therapeutic abilities in lung injury by increasing interleukin (IL)-10 and IL-1RN levels. Stem Cells Transl Med 2:884-895

Cai S-x, Liu A-r, Chen S, He H-l, Chen Q-h, Xu J-Y, Pan C, Yang Y, Guo F-M, Huang Y-z et al (2015) Activation of Wnt/ß-catenin signalling promotes mesenchymal stem cells to repair injured alveolar epithelium induced by lipopolysaccharide in mice. Stem Cell Res Ther 6:65

Cao B, Wang Y, Wen D, Liu W, Wang J, Fan G, Ruan L, Song B, Cai Y, Wei M et al (2020) A trial of Lopinavir-Ritonavir in adults hospitalized with severe Covid-19. N Engl J Med. https://doi.org/ 10.1056/NEJMoa2001282

Chacko SM, Ahmed S, Selvendiran K, Kuppusamy ML, Khan M, Kuppusamy P (2010) Hypoxic preconditioning induces the expression of prosurvival and proangiogenic markers in mesenchymal stem cells. Am J Physiol Cell Physiol 299:C1562C1570

Chan MCW, Kuok DIT, Leung CYH, Hui KPY, Valkenburg SA, Lau EHY, Nicholls JM, Fang X, Guan Y, Lee JW et al (2016) Human 
mesenchymal stromal cells reduce influenza A H5N1-associated acute lung injury in vitro and in vivo. Proc Natl Acad Sci USA 113:3621-3626

Chan JF-W, Yuan S, Kok K-H, To KK-W, Chu H, Yang J, Xing F, Liu J, Yip CC-Y, Poon RW-S et al (2020) A familial cluster of pneumonia associated with the 2019 novel coronavirus indicating person-to-person transmission: a study of a family cluster. The Lancet. https://doi.org/10.1016/S0140-6736(20)30154-9

Chen J, Li C, Gao X, Li C, Liang Z, Yu L, Li Y, Xiao X, Chen L (2013) Keratinocyte growth factor gene delivery via mesenchymal stem cells protects against lipopolysaccharide-induced acute lung injury in mice. PLoS ONE 8:e83303

Chen J, Li Y, Hao H, Li C, Du Y, Hu Y, Li J, Liang Z, Li C, Liu J et al (2015) Mesenchymal stem cell conditioned medium promotes proliferation and migration of alveolar epithelial cells under septic conditions in vitro via the JNK-P38 signaling pathway. Cell Physiol Biochem 37:1830-1846

Chen S, Chen X, Wu X, Wei S, Han W, Lin J, Kang M, Chen L (2017a) Hepatocyte growth factor-modified mesenchymal stem cells improve ischemia/reperfusion-induced acute lung injury in rats. Gene Ther 24:3-11

Chen H-X, Xiang H, Xu W-H, Li M, Yuan J, Liu J, Sun W-J, Zhang R, Li J, Ren Z-Q et al (2017b) Manganese superoxide dismutase gene-modified mesenchymal stem cells attenuate acute radiation-induced lung injury. Hum Gene Ther 28:523-532

Chen X, Zhang Y, Wang W, Liu Z, Meng J, Han Z (2018) Mesenchymal stem cells modified with heme oxygenase- 1 have enhanced paracrine function and attenuate lipopolysaccharideinduced inflammatory and oxidative damage in pulmonary microvascular endothelial cells. Cell Physiol Biochem 49:101122

Chen X-X, Tang L, Han Z-H, Wang W-J, Meng J-G (2019a) Coculture with bone marrow-derived mesenchymal stem cells attenuates inflammation and apoptosis in lipopolysaccharidestimulated alveolar epithelial cells via enhanced secretion of keratinocyte growth factor and angiopoietin-1 modulating the Tolllike receptor-4 signal pathway. Mol Med Rep 19:1891-1902

Chen X, Wu S, Tang L, Ma L, Wang F, Feng H, Meng J, Han Z (2019b) Mesenchymal stem cells overexpressing heme oxygenase-1 ameliorate lipopolysaccharide-induced acute lung injury in rats. J Cell Physiol 234:7301-7319

Chen H, Guo J, Wang C, Luo F, Yu X, Zhang W, Li J, Zhao D, Xu D, Gong $Q$ et al (2020a) Clinical characteristics and intrauterine vertical transmission potential of COVID-19 infection in nine pregnant women: a retrospective review of medical records. The Lancet 395:809-815

Chen T, Di Wu, Chen H, Yan W, Yang D, Chen G, Ma K, Xu D, Yu H, Wang $\mathrm{H}$ et al (2020b) Clinical characteristics of 113 deceased patients with coronavirus disease 2019: retrospective study. BMJ 368:m1091

Chen J, Hu C, Chen L, Tang L, Zhu Y, Xu X, Chen L, Gao H, Lu X, Yu $L$ et al (2020c) Clinical study of mesenchymal stem cell treating acute respiratory distress syndrome induced by epidemic Influenza A (H7N9) infection, a hint for COVID-19 treatment. Engineering (Beijing). https://doi.org/10.1016/j.eng.2020.02.006

Chinazzi M, Davis JT, Ajelli M, Gioannini C, Litvinova M, Merler S, Pastore Y, Piontti A, Mu K, Rossi L et al (2020) The effect of travel restrictions on the spread of the 2019 novel coronavirus (COVID19) outbreak. Science. https://doi.org/10.1126/science.aba9757

Devaney J, Horie S, Masterson C, Elliman S, Barry F, O'Brien T, Curley GF, O'Toole D, Laffey JG (2015) Human mesenchymal stromal cells decrease the severity of acute lung injury induced by $E$. coli in the rat. Thorax 70:625-635

Fang X, Neyrinck AP, Matthay MA, Lee JW (2010) Allogeneic human mesenchymal stem cells restore epithelial protein permeability in cultured human alveolar type II cells by secretion of angiopoietin1. J Biol Chem 285:26211-26222

Fischer UM, Harting MT, Jimenez F, Monzon-Posadas WO, Xue H, Savitz SI, Laine GA, Cox CS (2009) Pulmonary passage is a major obstacle for intravenous stem cell delivery: the pulmonary first-pass effect. Stem Cells Dev 18:683-692

Garcia-Olmo D, Schwartz DA (2015) Cumulative evidence that mesenchymal stem cells promote healing of perianal fistulas of patients with Crohn's disease-going from bench to bedside. Gastroenterology 149:853-857

Ghinai I, McPherson TD, Hunter JC, Kirking HL, Christiansen D, Joshi K, Rubin R, Morales-Estrada S, Black SR, Pacilli M et al (2020) First known person-to-person transmission of severe acute respiratory syndrome coronavirus 2 (SARS-CoV-2) in the USA. The Lancet. https://doi.org/10.1016/S0140-6736(20)306073

Golpanian S, Wolf A, Hatzistergos KE, Hare JM (2016) Rebuilding the damaged heart: mesenchymal stem cells, cell-based therapy, and engineered heart tissue. Physiol Rev 96:1127-1168

Goolaerts A, Pellan-Randrianarison N, Larghero J, Vanneaux V, Uzunhan Y, Gille T, Dard N, Planès C, Matthay MA, Clerici C (2014) Conditioned media from mesenchymal stromal cells restore sodium transport and preserve epithelial permeability in an in vitro model of acute alveolar injury. Am J Physiol Lung Cell Mol Physiol 306:L975-L985

Goyal P, Choi JJ, Pinheiro LC, Schenck EJ, Chen R, Jabri A, Satlin MJ, Campion TR, Nahid M, Ringel JB et al (2020) Clinical characteristics of Covid-19 in New York City. N Engl J Med. https://doi.org/10.1056/NEJMc2010419

Guan W-J, Ni Z-Y, Hu Y, Liang W-H, Ou C-Q, He J-X, Liu L, Shan H, Lei C-L, Hui DSC et al (2020) Clinical characteristics of coronavirus disease 2019 in China. N Engl J Med. https://doi. org/10.1056/NEJMoa2002032

Güldner A, Maron-Gutierrez T, Abreu SC, Xisto DG, Senegaglia AC, Barcelos PRdS, Silva JD, Brofman P, de Abreu MG, Rocco PRM (2015) Expanded endothelial progenitor cells mitigate lung injury in septic mice. Stem Cell Res Ther 6:230

Gupta N, Krasnodembskaya A, Kapetanaki M, Mouded M, Tan X, Serikov V, Matthay MA (2012) Mesenchymal stem cells enhance survival and bacterial clearance in murine Escherichia coli pneumonia. Thorax 67:533-539

Haberman R, Axelrad J, Chen A, Castillo R, Yan Di, Izmirly P, Neimann A, Adhikari S, Hudesman D, Scher JU (2020) Covid-19 in immune-mediated inflammatory diseases—case series from New York. N Engl J Med. https://doi.org/10.1056/NEJMc2009567

Han J, Li Y, Li Y (2019) Strategies to enhance mesenchymal stem cell-based therapies for acute respiratory distress syndrome. Stem Cells Int 2019:5432134 
Hao Q, Zhu Y-g, Monsel A, Gennai S, Lee T, Xu F, Lee J-W (2015) Study of bone marrow and embryonic stem cell-derived human mesenchymal stem cells for treatment of escherichia coli endotoxin-induced acute lung injury in mice. Stem Cells Transl Med 4:832-840

Hao Q, Gudapati V, Monsel A, Park JH, Hu S, Kato H, Lee JH, Zhou L, He H, Lee JW (2019) Mesenchymal stem cell-derived extracellular vesicles decrease lung injury in mice. J Immunol 203:1961-1972

He H-I, Liu L, Chen Q-h, Cai S-x, Han J-B, Hu S-L, Chun P, Yang Y, Guo F-M, Huang Y-z et al (2015) MSCs modified with ACE2 restore endothelial function following LPS challenge by inhibiting the activation of RAS. J Cell Physiol 230:691-701

Holshue ML, DeBolt C, Lindquist S, Lofy KH, Wiesman J, Bruce H, Spitters C, Ericson K, Wilkerson S, Tural A et al (2020) First case of 2019 novel coronavirus in the United States. N Engl J Med. https://doi.org/10.1056/NEJMoa2001191

Hu S, Li J, Xu X, Liu A, He H, Xu J, Chen Q, Liu S, Liu L, Qiu H et al (2016) The hepatocyte growth factor-expressing character is required for mesenchymal stem cells to protect the lung injured by lipopolysaccharide in vivo. Stem Cell Res Ther 7:66

Hu S, Park J, Liu A, Lee J, Zhang X, Hao Q, Lee J-W (2018) Mesenchymal stem cell microvesicles restore protein permeability across primary cultures of injured human lung microvascular endothelial cells. Stem Cells Transl Med 7:615-624

Huang Z, Liu H, Zhang X, Wen G, Zhu C, Zhao Y, Niu W, Qin Y, Chen $\mathrm{H}$, Bai $\mathrm{C}$ et al (2018) Transcriptomic analysis of lung tissues after hUC-MSCs and FTY720 treatment of lipopolysaccharideinduced acute lung injury in mouse models. Int Immunopharmacol 63:26-34

lonescu L, Byrne RN, van Haaften T, Vadivel A, Alphonse RS, ReyParra GJ, Weissmann G, Hall A, Eaton F, Thébaud B (2012) Stem cell conditioned medium improves acute lung injury in mice: in vivo evidence for stem cell paracrine action. Am J Physiol Lung Cell Mol Physiol 303:L967-L977

Islam D, Huang Y, Fanelli V, Delsedime L, Wu S, Khang J, Han B, Grassi A, Li M, Xu Y et al (2019) Identification and modulation of microenvironment is crucial for effective mesenchymal stromal cell therapy in acute lung injury. Am J Respir Crit Care Med 199:1214-1224

Jackson MV, Morrison TJ, Doherty DF, McAuley DF, Matthay MA, Kissenpfennig A, O'Kane CM, Krasnodembskaya AD (2016) Mitochondrial transfer via tunneling nanotubes is an important mechanism by which mesenchymal stem cells enhance macrophage phagocytosis in the in vitro and in vivo models of ARDS. Stem Cells 34:2210-2223

Kandel N, Chungong S, Omaar A, Xing J (2020) Health security capacities in the context of COVID-19 outbreak: an analysis of International Health Regulations annual report data from 182 countries. The Lancet. https://doi.org/10.1016/S0140-6736(20) 30553-5

Kim ES, Chang YS, Choi SJ, Kim JK, Yoo HS, Ahn SY, Sung DK, Kim SY, Park YR, Park WS (2011) Intratracheal transplantation of human umbilical cord blood-derived mesenchymal stem cells attenuates Escherichia coli-induced acute lung injury in mice. Respir Res 12:108
Koff WC, Williams MA (2020) Covid-19 and immunity in aging populations-a new research agenda. N Engl J Med. https://doi. org/10.1056/NEJMp2006761

Krasnodembskaya A, Song Y, Fang X, Gupta N, Serikov V, Lee J-W, Matthay MA (2010) antibacterial effect of human mesenchymal stem cells is mediated in part from secretion of the antimicrobial peptide LL-37. Stem Cells 28:2229-2238

Krasnodembskaya A, Samarani G, Song Y, Zhuo H, Su X, Lee J-W, Gupta N, Petrini M, Matthay MA (2012) Human mesenchymal stem cells reduce mortality and bacteremia in gram-negative sepsis in mice in part by enhancing the phagocytic activity of blood monocytes. Am J Physiol Lung Cell Mol Physiol 302: L1003-L1013

Kucharski AJ, Russell TW, Diamond C, Liu Y, Edmunds J, Funk S, Eggo RM, Sun F, Jit M, Munday JD et al (2020) Early dynamics of transmission and control of COVID-19: a mathematical modelling study. Lancet Infect Dis. https://doi.org/10.1016/S1473-3099(20) 30144-4

Laffey JG, Matthay MA (2017) Fifty years of research in ARDS. Cellbased therapy for acute respiratory distress syndrome. biology and potential therapeutic value. Am J Respir Crit Care Med 196:266-273

Lan Y-W, Choo K-B, Chen C-M, Hung T-H, Chen Y-B, Hsieh C-H, Kuo H-P, Chong K-Y (2015) Hypoxia-preconditioned mesenchymal stem cells attenuate bleomycin-induced pulmonary fibrosis. Stem Cell Res Ther 6:97

Lan J, Ge J, Yu J, Shan S, Zhou H, Fan S, Zhang Q, Shi X, Wang Q, Zhang L, Wang $X$ (2020) Structure of the SARS-CoV-2 spike receptor-binding domain bound to the ACE2 receptor. Nature. https://doi.org/10.1038/s41586-020-2180-5

Le HT, Nguyen LV, Tran DM, Do HT, Tran HT, Le YT, Phan PH (2020) The first infant case of COVID-19 acquired from a secondary transmission in Vietnam. Lancet Child Adolesc Health. https://doi.org/10.1016/S2352-4642(20)30091-2

Le Blanc K, Mougiakakos D (2012) Multipotent mesenchymal stromal cells and the innate immune system. Nat Rev Immunol 12:383-396

Lee C-W, Chen Y-F, Wu H-H, Lee OK (2018) Historical perspectives and advances in mesenchymal stem cell research for the treatment of liver diseases. Gastroenterology 154:46-56

Lee JH, Park J, Lee J-W (2019) Therapeutic use of mesenchymal stem cell-derived extracellular vesicles in acute lung injury. Transfusion 59:876-883

Lee RH, Pulin AA, Seo MJ, Kota DJ, Ylostalo J, Larson BL, Semprun-Prieto L, Delafontaine P, Prockop DJ (2009) Intravenous hMSCs improve myocardial infarction in mice because cells embolized in lung are activated to secrete the antiinflammatory protein TSG-6. Cell Stem Cell 5:54-63

Lee JW, Krasnodembskaya A, McKenna DH, Song Y, Abbott J, Matthay MA (2013) Therapeutic effects of human mesenchymal stem cells in ex vivo human lungs injured with live bacteria. Am J Respir Crit Care Med 187:751-760

Leng Z, Zhu R, Hou W, Feng Y, Yang Y, Han Q, Shan G, Meng F, Du D, Wang $S$ et al (2020) Transplantation of ACE2-mesenchymal stem cells improves the outcome of patients with COVID-19 pneumonia. Aging Dis 11:216-228 
Li B, Zhang H, Zeng M, He W, Li M, Huang X, Deng DYB, Wu J (2015) Bone marrow mesenchymal stem cells protect alveolar macrophages from lipopolysaccharide-induced apoptosis partially by inhibiting the $W n t / \beta$-catenin pathway. Cell Biol Int 39:192-200

Li D, Liu Q, Qi L, Dai X, Liu H, Wang Y (2016) Low levels of TGF- $\beta 1$ enhance human umbilical cord-derived mesenchymal stem cell fibronectin production and extend survival time in a rat model of lipopolysaccharide-induced acute lung injury. Mol Med Rep 14:1681-1692

Li Y, Shi X, Yang L, Mou Y, Li Y, Dang R, Li C (2017) Hypoxia promotes the skewed differentiation of umbilical cord mesenchymal stem cells toward type II alveolar epithelial cells by regulating microRNA-145. Gene 630:68-75

Li M-Y, Li L, Zhang Y, Wang X-S (2020) Expression of the SARSCoV-2 cell receptor gene ACE2 in a wide variety of human tissues. Infect Dis Poverty 9:45

Liao M, Liu Y, Yuan J, Wen Y, Xu G, Zhao J, Chen L, Li J, Wang X, Wang $F$ et al (2020) The landscape of lung bronchoalveolar immune cells in COVID-19 revealed by single-cell RNA sequencing

Liu A-r, Liu Le, Chen S, Yang Y, Zhao H-J, Liu L, Guo F-M, Lu X-M, Qu H-B (2013) Activation of canonical wnt pathway promotes differentiation of mouse bone marrow-derived MSCs into type II alveolar epithelial cells, confers resistance to oxidative stress, and promotes their migration to injured lung tissue in vitro. $\mathrm{J}$ Cell Physiol 228:1270-1283

Lopes-Pacheco M, Robba C, Rocco PRM, Pelosi P (2019) Current understanding of the therapeutic benefits of mesenchymal stem cells in acute respiratory distress syndrome. Cell Biol Toxicol. https://doi.org/10.1007/s10565-019-09493-5

Lu R, Zhao X, Li J, Niu P, Yang B, Wu H, Wang W, Song H, Huang B, Zhu N et al (2020) Genomic characterisation and epidemiology of 2019 novel coronavirus: implications for virus origins and receptor binding. The Lancet. https://doi.org/10.1016/S01406736(20)30251-8

Maron-Gutierrez T, Silva JD, Asensi KD, Bakker-Abreu I, Shan Y, Diaz BL, Goldenberg RCS, Mei SHJ, Stewart DJ, Morales MM et al (2013) Effects of mesenchymal stem cell therapy on the time course of pulmonary remodeling depend on the etiology of lung injury in mice. Crit Care Med 41:e319-e333

Martínez-González I, Roca O, Masclans JR, Moreno R, Salcedo MT, Baekelandt V, Cruz MJ, Rello J, Aran JM (2013) Human mesenchymal stem cells overexpressing the IL-33 antagonist soluble IL-1 receptor-like-1 attenuate endotoxin-induced acute lung injury. Am J Respir Cell Mol Biol 49:552-562

Matthay MA, Calfee CS, Zhuo H, Thompson BT, Wilson JG, Levitt JE, Rogers AJ, Gotts JE, Wiener-Kronish JP, Bajwa EK et al (2019) Treatment with allogeneic mesenchymal stromal cells for moderate to severe acute respiratory distress syndrome (START study): a randomised phase 2a safety trial. Lancet Respir Med 7:154-162

McIntyre LA, Moher D, Fergusson DA, Sullivan KJ, Mei SHJ, Lalu M, Marshall J, Mcleod M, Griffin G, Grimshaw J et al (2016) Efficacy of mesenchymal stromal cell therapy for acute lung injury in preclinical animal models: a systematic review. PLoS ONE 11: e0147170
Mehta P, McAuley DF, Brown M, Sanchez E, Tattersall RS, Manson JJ (2020) COVID-19: consider cytokine storm syndromes and immunosuppression. The Lancet 395:1033-1034

Mei SHJ, McCarter SD, Deng Y, Parker CH, Liles WC, Stewart DJ (2007) Prevention of LPS-induced acute lung injury in mice by mesenchymal stem cells overexpressing angiopoietin 1. PLoS Med 4:e269

Meng S-S, Guo F-M, Zhang X-W, Chang W, Peng F, Qiu H-B, Yang $Y$ (2019) mTOR/STAT-3 pathway mediates mesenchymal stem cell-secreted hepatocyte growth factor protective effects against lipopolysaccharide-induced vascular endothelial barrier dysfunction and apoptosis. J Cell Biochem 120:3637-3650

Millar JE, von Bahr V, Malfertheiner MV, Ki KK, Redd MA, Bartnikowski N, Suen JY, McAuley DF, Fraser JF (2019) Administration of mesenchymal stem cells during ECMO results in a rapid decline in oxygenator performance. Thorax 74:194-196

Mokhber Dezfouli MR, Jabbari Fakhr M, Sadeghian Chaleshtori S, Dehghan MM, Vajhi A, Mokhtari R (2018) Intrapulmonary autologous transplant of bone marrow-derived mesenchymal stromal cells improves lipopolysaccharide-induced acute respiratory distress syndrome in rabbit. Crit Care 22:353

Molendijk I, Bonsing BA, Roelofs H, Peeters KCMJ, Wasser MNJM, Dijkstra G, van der Woude CJ, Duijvestein M, Veenendaal RA, Zwaginga J-J et al (2015) Allogeneic bone marrow-derived mesenchymal stromal cells promote healing of refractory perianal fistulas in patients with Crohn's disease. Gastroenterology 149:918-27.e6

Monteil V, Kwon H, Prado P, Hagelkrüys A, Wimmer RA, Stahl M, Leopoldi A, Garreta E, Hurtado Del Pozo C, Prosper F et al (2020) Inhibition of SARS-CoV-2 infections in engineered human tissues using clinical-grade soluble human ACE2. Cell. https:// doi.org/10.1016/j.cell.2020.04.004

Papazian L, Aubron C, Brochard L, Chiche J-D, Combes A, Dreyfuss D, Forel J-M, Guérin C, Jaber S, Mekontso-Dessap A et al (2019) Formal guidelines: management of acute respiratory distress syndrome. Ann Intensiv Care 9:69

Park J, Kim S, Lim H, Liu A, Hu S, Lee J, Zhuo H, Hao Q, Matthay MA, Lee J-W (2019) Therapeutic effects of human mesenchymal stem cell microvesicles in an ex vivo perfused human lung injured with severe E. coli pneumonia. Thorax 74:43-50

Pedrazza L, Cunha AA, Luft C, Nunes NK, Schimitz F, Gassen RB, Breda RV, Donadio MVF, Souza Wyse AT, Pitrez PMC et al (2017) Mesenchymal stem cells improves survival in LPSinduced acute lung injury acting through inhibition of NETs formation. J Cell Physiol 232:3552-3564

Perico L, Morigi M, Rota C, Breno M, Mele C, Noris M, Introna M, Capelli C, Longaretti L, Rottoli D et al (2017) Human mesenchymal stromal cells transplanted into mice stimulate renal tubular cells and enhance mitochondrial function. Nat Commun 8:983

Qin Z-h, Xu J-f, Qu J-M, Zhang J, Sai Y, Chen C-m, Wu L, Yu L (2012) Intrapleural delivery of MSCs attenuates acute lung injury by paracrine/endocrine mechanism. J Cell Mol Med 16:27452753

Ranieri VM, Rubenfeld GD, Thompson BT, Ferguson ND, Caldwell E, Fan E, Camporota L, Slutsky AS (2012) Acute respiratory distress syndrome: the Berlin Definition. JAMA 307:2526-2533 
Ren H, Zhang Q, Wang J, Pan R (2018) Comparative effects of umbilical cord- and menstrual blood-derived MSCs in repairing acute lung injury. Stem Cells Int 2018:7873625

Ronco C, Reis T (2020) Kidney involvement in COVID-19 and rationale for extracorporeal therapies. Nat Rev Nephrol. https:// doi.org/10.1038/s41581-020-0284-7

Schett G, Sticherling M, Neurath MF (2020) COVID-19: risk for cytokine targeting in chronic inflammatory diseases? Nat Rev Immunol 20:271-272

Shang J, Ye G, Shi K, Wan Y, Luo C, Aihara H, Geng Q, Auerbach A, Li F (2020) Structural basis of receptor recognition by SARSCoV-2. Nature. https://doi.org/10.1038/s41586-020-2179-y

Shao Y, Shen J, Zhou F, He D (2018) Mesenchymal stem cells overexpressing Ang1 attenuates phosgene-induced acute lung injury in rats. Inhal Toxicol 30:313-320

Shao Y, Zhou F, He D, Zhang L, Shen J (2019) Overexpression of CXCR7 promotes mesenchymal stem cells to repair phosgeneinduced acute lung injury in rats. Biomed Pharmacother 109:1233-1239

Silva JD, Lopes-Pacheco M, Paz AHR, Cruz FF, Melo EB, de Oliveira MV, Xisto DG, Capelozzi VL, Morales MM, Pelosi P et al (2018) Mesenchymal stem cells from bone marrow, adipose tissue, and lung tissue differentially mitigate lung and distal organ damage in experimental acute respiratory distress syndrome. Crit Care Med 46:e132-e140

Simonson OE, Mougiakakos D, Heldring N, Bassi G, Johansson HJ, Dalén M, Jitschin R, Rodin S, Corbascio M, El Andaloussi S et al (2015) In vivo effects of mesenchymal stromal cells in two patients with severe acute respiratory distress syndrome. Stem Cells Transl Med 4:1199-1213

Stappenbeck TS, Miyoshi H (2009) The role of stromal stem cells in tissue regeneration and wound repair. Science 324:1666-1669

Stebbing J, Phelan A, Griffin I, Tucker C, Oechsle O, Smith D, Richardson P (2020) COVID-19: combining antiviral and antiinflammatory treatments. Lancet Infect Dis 20:400-402

Su VY-F, Lin C-S, Hung S-C, Yang K-Y (2019) Mesenchymal stem cell-conditioned medium induces neutrophil apoptosis associated with inhibition of the NF-KB pathway in endotoxin-induced acute lung injury. Int J Mol Sci. https://doi.org/10.3390/ijms20092208

Sun K, Chen J, Viboud C (2020) Early epidemiological analysis of the coronavirus disease 2019 outbreak based on crowdsourced data: a population-level observational study. Lancet Digit Health 2:e201-e208

Sung DK, Chang YS, Sung S, Yoo HS, Ahn SY, Park WS (2016) Antibacterial effect of mesenchymal stem cells against Escherichia coli is mediated by secretion of beta- defensin- 2 via toll- like receptor 4 signalling. Cell Microbiol 18:424-436

van de Veerdonk FL, Netea MG, van Deuren M, van der Meer JW, de Mast Q, Brüggemann RJ, van der Hoeven $\mathrm{H}$ (2020) Kallikreinkinin blockade in patients with COVID-19 to prevent acute respiratory distress syndrome. Elife. https://doi.org/10.7554/eLife. 57555

Vaninov N (2020) In the eye of the COVID-19 cytokine storm. Nat Rev Immunol 20:277

Varga Z, Flammer AJ, Steiger P, Haberecker M, Andermatt R, Zinkernagel AS, Mehra MR, Schuepbach RA, Ruschitzka F,
Moch H (2020) Endothelial cell infection and endotheliitis in COVID-19. The Lancet 395:1417-1418

Walls AC, Park Y-J, Tortorici MA, Wall A, McGuire AT, Veesler D (2020) Structure, function, and antigenicity of the SARS-CoV-2 spike glycoprotein. Cell 181:281-292.e6

Wang Y-Y, Li X-Z, Wang L-B (2013) Therapeutic implications of mesenchymal stem cells in acute lung injury/acute respiratory distress syndrome. Stem Cell Res Ther 4:45

Wang L, Shi M, Tong L, Wang J, Ji S, Bi J, Chen C, Jiang J, Bai C, Zhou J et al (2019) Lung-resident mesenchymal stem cells promote repair of LPS-induced acute lung injury via regulating the balance of regulatory $\mathrm{T}$ cells and Th17 cells. Inflammation 42:199-210

Wang L, He W, Yu X, Hu D, Bao M, Liu H, Zhou J, Jiang H (2020a) Coronavirus disease 2019 in elderly patients: characteristics and prognostic factors based on 4-week follow-up. J Infect. https://doi. org/10.1016/j.jinf.2020.03.019

Wang Q, Zhang Y, Wu L, Niu S, Song C, Zhang Z, Lu G, Qiao C, Hu Y, Yuen K-Y et al (2020b) Structural and functional basis of SARS-CoV-2 entry by using human ACE2. Cell. https://doi.org/ 10.1016/j.cell.2020.03.045

Wilson JG, Liu KD, Zhuo H, Caballero L, McMillan M, Fang X, Cosgrove K, Vojnik R, Calfee CS, Lee J-W et al (2015) Mesenchymal stem (stromal) cells for treatment of ARDS: a phase 1 clinical trial. Lancet Respir Med 3:24-32

Xiang B, Chen L, Wang X, Zhao Y, Wang Y, Xiang C (2017) Transplantation of menstrual blood-derived mesenchymal stem cells promotes the repair of LPS-induced acute lung injury. Int J Mol Sci. https://doi.org/10.3390/ijms18040689

Xu J, Qu J, Cao L, Sai Y, Chen C, He L, Yu L (2008) Mesenchymal stem cell-based angiopoietin-1 gene therapy for acute lung injury induced by lipopolysaccharide in mice. J Pathol 214:472-481

Xu X-P, Huang L-L, Hu S-L, Han J-B, He H-I, Xu J-Y, Xie J-F, Liu A-r, Liu S-Q, Liu L et al (2018) Genetic modification of mesenchymal stem cells overexpressing angiotensin II Type 2 receptor increases cell migration to injured lung in LPS-induced acute lung injury mice. Stem Cells Transl Med 7:721-730

Xu N, Shao Y, Ye K, Qu Y, Memet O, He D, Shen J (2019) Mesenchymal stem cell-derived exosomes attenuate phosgeneinduced acute lung injury in rats. Inhal Toxicol 31:52-60

Xu Y, Li X, Zhu B, Liang H, Fang C, Gong Y, Guo Q, Sun X, Zhao D, Shen $\mathrm{J}$ et al (2020a) Characteristics of pediatric SARS-CoV-2 infection and potential evidence for persistent fecal viral shedding. Nat Med 395:470

Xu Z, Shi L, Wang Y, Zhang J, Huang L, Zhang C, Liu S, Zhao P, Liu $\mathrm{H}$, Zhu $\mathrm{L}$ et al (2020b) Pathological findings of COVID-19 associated with acute respiratory distress syndrome. Lancet Respir Med 8:420-422

Yan X, Fu X, Jia Y, Ma X, Tao J, Yang T, Ma H, Liang X, Liu X, Yang J et al (2019) Nrf2/Keap1/ARE signaling mediated an antioxidative protection of human placental mesenchymal stem cells of fetal origin in alveolar epithelial cells. Oxid Med Cell Longev 2019:2654910

Yan R, Zhang Y, Li Y, Xia L, Guo Y, Zhou Q (2020) Structural basis for the recognition of the SARS-CoV-2 by full-length human ACE2. Science. https://doi.org/10.1126/science.abb2762 
Yang J-X, Zhang N, Wang H-W, Gao P, Yang Q-P, Wen Q-P (2015a) CXCR4 receptor overexpression in mesenchymal stem cells facilitates treatment of acute lung injury in rats. $\mathrm{J}$ Biol Chem 290:1994-2006

Yang Y, Chen Q-h, Liu A-r, Xu X-P, Han J-B, Qiu H-B (2015b) Synergism of MSC-secreted HGF and VEGF in stabilising endothelial barrier function upon lipopolysaccharide stimulation via the Rac1 pathway. Stem Cell Res Ther 6:250

Yang Y, Shen C, Li J, Yuan J, Wei J, Huang F, Wang F, Li G, Li Y, Xing $L$ et al (2020) Plasma IP-10 and MCP-3 levels are highly associated with disease severity and predict the progression of COVID-19. J Allergy Clin Immunol. https://doi.org/10.1016/j.jaci. 2020.04.027

Yuan M, Wu NC, Zhu X, Lee C-CD, So RTY, Lv H, Mok CKP, Wilson IA (2020) A highly conserved cryptic epitope in the receptorbinding domains of SARS-CoV-2 and SARS-CoV. Science

Zhang W, Liu L, Huo Y, Yang Y, Wang Y (2014) Hypoxia-pretreated human MSCs attenuate acute kidney injury through enhanced angiogenic and antioxidative capacities. Biomed Res Int 2014:462472

Zhang C, Zhu Y, Wang J, Hou L, Li W, An H (2019a) CXCR4overexpressing umbilical cord mesenchymal stem cells enhance protection against radiation-induced lung injury. Stem Cells Int 2019:2457082

Zhang L, Li Q, Liu W, Liu Z, Shen H, Zhao M (2019b) Mesenchymal stem cells alleviate acute lung injury and inflammatory responses induced by paraquat poisoning. Med Sci Monit 25:2623-2632

Zhang X, Chen J, Xue M, Tang Y, Xu J, Liu L, Huang Y, Yang Y, Qiu H, Guo F (2019c) Overexpressing p130/E2F4 in mesenchymal stem cells facilitates the repair of injured alveolar epithelial cells in LPS-induced ARDS mice. Stem Cell Res Ther 10:74

Zhang H, Penninger JM, Li Y, Zhong N, Slutsky AS (2020) Angiotensin-converting enzyme 2 (ACE2) as a SARS-CoV-2 receptor: molecular mechanisms and potential therapeutic target. Intensiv Care Med 46:586-590
Zhao Y-F, Xiong W, Wu X-L (2014) Mesenchymal stem cell-based developmental endothelial locus-1 gene therapy for acute lung injury induced by lipopolysaccharide in mice. Mol Med Rep 9:1583-1589

Zhao Y, Zhao Z, Wang Y, Zhou Y, Ma Y, Zuo W (2020) Single-cell RNA expression profiling of ACE2, the receptor of SARS-CoV-2

Zheng G, Huang L, Tong H, Shu Q, Hu Y, Ge M, Deng K, Zhang L, Zou B, Cheng B et al (2014) Treatment of acute respiratory distress syndrome with allogeneic adipose-derived mesenchymal stem cells: a randomized, placebo-controlled pilot study. Respir Res 15:39

Zheng M, Gao Y, Wang G, Song G, Liu S, Sun D, Xu Y, Tian Z (2020) Functional exhaustion of antiviral lymphocytes in COVID-19 patients. Cell Mol Immunol 17:533-535

Zhou Z, You Z (2016) Mesenchymal stem cells alleviate LPSinduced acute lung injury in mice by MiR-142a-5p-controlled pulmonary endothelial cell autophagy. Cell Physiol Biochem 38:258-266

Zhou P, Yang X-L, Wang X-G, Hu B, Zhang L, Zhang W, Si H-R, Zhu Y, Li B, Huang C-L et al (2020a) A pneumonia outbreak associated with a new coronavirus of probable bat origin. Nature 579:270-273

Zhou Y, Fu B, Zheng X, Wang D, Zhao C, Qi Y, Sun R, Tian Z, Xu X, Wei $H$ (2020b) Pathogenic T cells and inflammatory monocytes incite inflammatory storm in severe COVID-19 patients. Natl Sci Rev. https://doi.org/10.1093/nsr/nwaa041

Zhu H, Xiong Y, Xia Y, Zhang R, Tian D, Wang T, Dai J, Wang L, Yao $\mathrm{H}$, Jiang $\mathrm{H}$ et al (2017) Therapeutic effects of human umbilical cord-derived mesenchymal stem cells in acute lung injury mice. Sci Rep 7:39889

Zhu N, Zhang D, Wang W, Li X, Yang B, Song J, Zhao X, Huang B, Shi W, Lu R et al (2020) A novel coronavirus from patients with pneumonia in China, 2019. N Engl J Med. https://doi.org/10.1056/ NEJMoa2001017 